\title{
Exclusion of the familial Mediterranean fever locus as a susceptibility region for autosomal dominant familial Hibernian fever
}

M F McDermott, E M McDermott, K A Quane, L C Jones, B W Ogunkolade, D Curtis, F Waldron-Lynch, M Phelan, G A Hitman, M G Molloy, R J Powell

\section{Medical Unit and Department of Psychiatry, \\ St Bartholomew's and \\ the Royal London \\ Hospital School of \\ Medicine and \\ Dentistry, \\ Whitechapel, London \\ E1 1BB, UK \\ M F McDermott \\ L C Jones \\ B W Ogunkolade \\ D Curtis \\ G A Hitman}

\section{Departments of}

Medicine and

Rheumatology,

National University of

Ireland, Cork, Ireland

K A Quane

$M$ Phelan

M G Molloy

\section{Department of}

Microbiology, National

University of Ireland,

Cork, Ireland

F Waldron-Lynch

Department of Clinical Immunology, Queen's Medical Centre,

University Hospital,

Nottingham NG7 2UH,

UK

E M McDermott

R J Powell

Correspondence to:

Dr McDermott.

Received 8 September 1997 Revised version accepted for publication

26 November 1997 dominant periodic fever. $\theta=$ genetic distance in centimorgans

\begin{tabular}{|c|c|c|c|c|c|c|c|c|c|}
\hline \multirow[b]{2}{*}{ Marker } & \multicolumn{9}{|l|}{$\theta$} \\
\hline & 0.0 & 0.01 & 0.05 & 0.10 & 0.15 & 0.20 & 0.25 & 0.30 & 0.40 \\
\hline \multicolumn{10}{|l|}{ Family A } \\
\hline S283 & -8.02 & -4.71 & -3.23 & -2.50 & -1.91 & -1.37 & -0.95 & -0.63 & -0.24 \\
\hline S2617 & -2.30 & -1.42 & -0.76 & -0.45 & 0.39 & -0.18 & -0.11 & -0.06 & -0.01 \\
\hline S423 & -2.36 & -2.28 & -1.84 & -1.17 & -0.69 & -0.37 & -0.17 & -0.05 & 0.04 \\
\hline$S 418$ & -8.56 & -6.33 & -3.75 & -2.31 & -1.49 & -0.95 & -0.58 & -0.33 & -0.06 \\
\hline Family B & & & & & & & & & \\
\hline S283 & -5.16 & -2.53 & -1.17 & -0.61 & -0.32 & -0.16 & -0.06 & -0.01 & 0.01 \\
\hline S2617 & -2.98 & -0.93 & -0.30 & -0.08 & 0.01 & 0.04 & 0.05 & 0.05 & 0.02 \\
\hline S423 & -2.43 & -2.18 & -1.31 & -0.78 & -0.48 & -0.29 & -0.16 & -0.09 & -0.01 \\
\hline S418 & -5.46 & -2.28 & -0.92 & -0.38 & -0.11 & 0.03 & 0.09 & 0.10 & 0.05 \\
\hline
\end{tabular}
inheritance of FHF is dominant whereas fevers with localised myalgia and painful
Autosomal dominant periodic fevers constitute a range of syndromes characterised by recurrent attacks of fever and abdominal pain. Familial Hibernian fever (FHF) has been described in only one United Kingdom based family, but two other Irish families have been found with similar clinical features. FHF resembles familial Mediterranean fever (FMF) in several clinical features, but the mode of FMF is recessive. We have investigated whether autosomal dominant periodic fevers, in particular FHF, map to the FMF susceptibility locus (MEFV) on chromosome 16p13.3. We have used informative microsatellite markers flanking this locus to genotype members of the three families mentioned above. Two point and multipoint lod scores definitively excluded linkage to MEFV in the two larger families. A haplotype study confirmed these findings, indicating that FHF is genotypically as well as phenotypically distinct from $F M F$.

$(\mathcal{O}$ Med Genet 1998;35:432-434)

Keywords: familial Mediterranean fever; autosomal dominant; periodic fever

Autosomal dominant periodic fever syndromes are a poorly categorised collection of conditions found in several ethnic groups including Austrians, ${ }^{1}$ Dutch, ${ }^{2}$ Finns, ${ }^{3}$ Germans, and Swiss. ${ }^{4}$ However, only familial Hibernian fever (FHF) has been specifically described as a separate clinical entity in one United Kingdom based family ${ }^{5}$ and two other Irish families have been reported with similar clinical features. ${ }^{6}$ The clinical presentation of FHF, characterised by recurrent attacks of abdominal pain and $\mathrm{n}$ program of the LINKAGE package. Multipoint analysis of the disease against D16S283, D16S2617, and D16S423 was performed using VITESSE. ${ }^{17}$ A dominant transmission model was specified, with age specific penetrances of $10 \%, 70 \%$, and $90 \%$ for people of age groups $<15$ years, 15 to 40 , and over 40 years, respectively. These values were based on our observations that there were no unaffected carriers, and that all affected cases had onset by the age of 40 and usually by the age of 25 . 
Family A

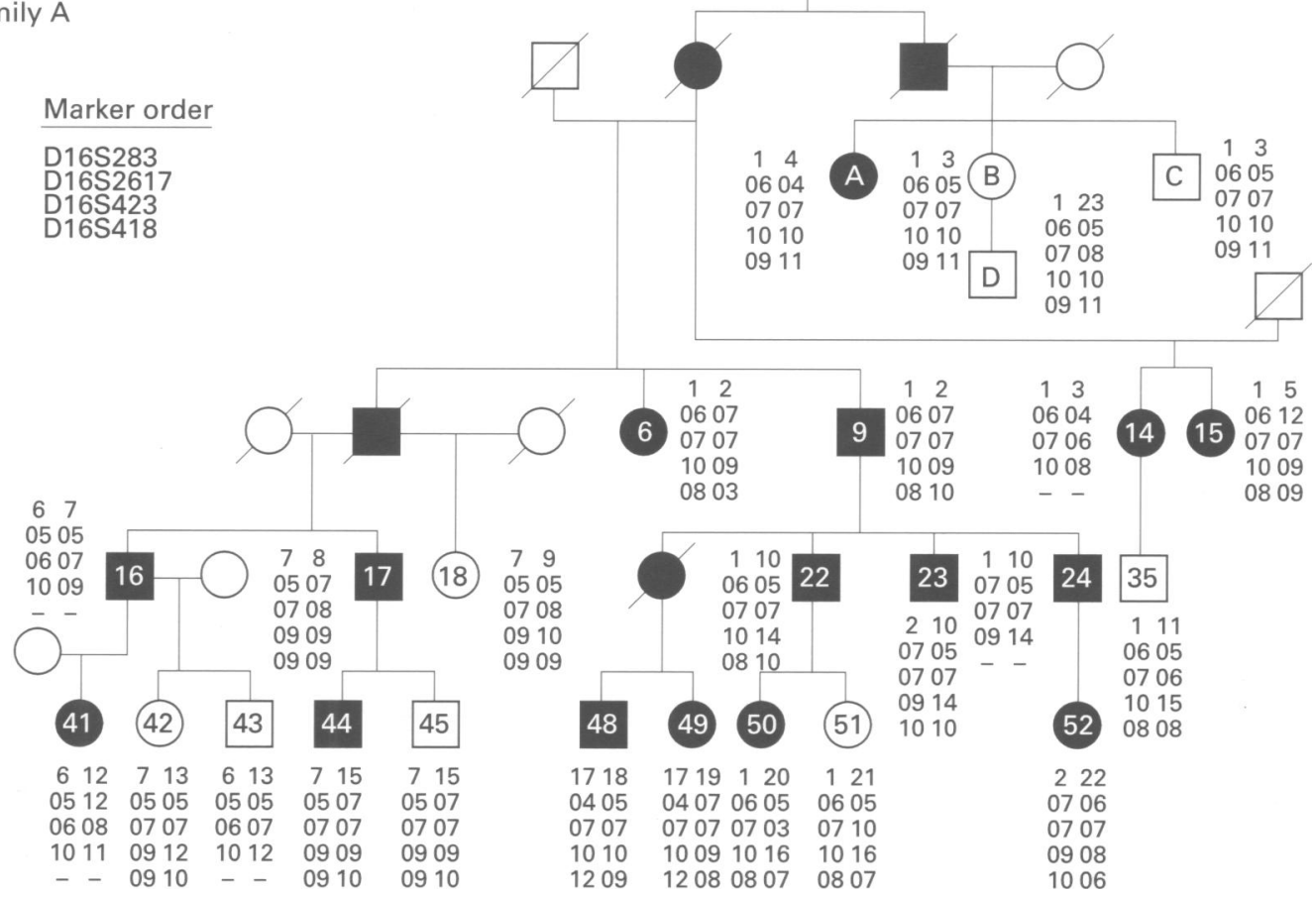

Family B

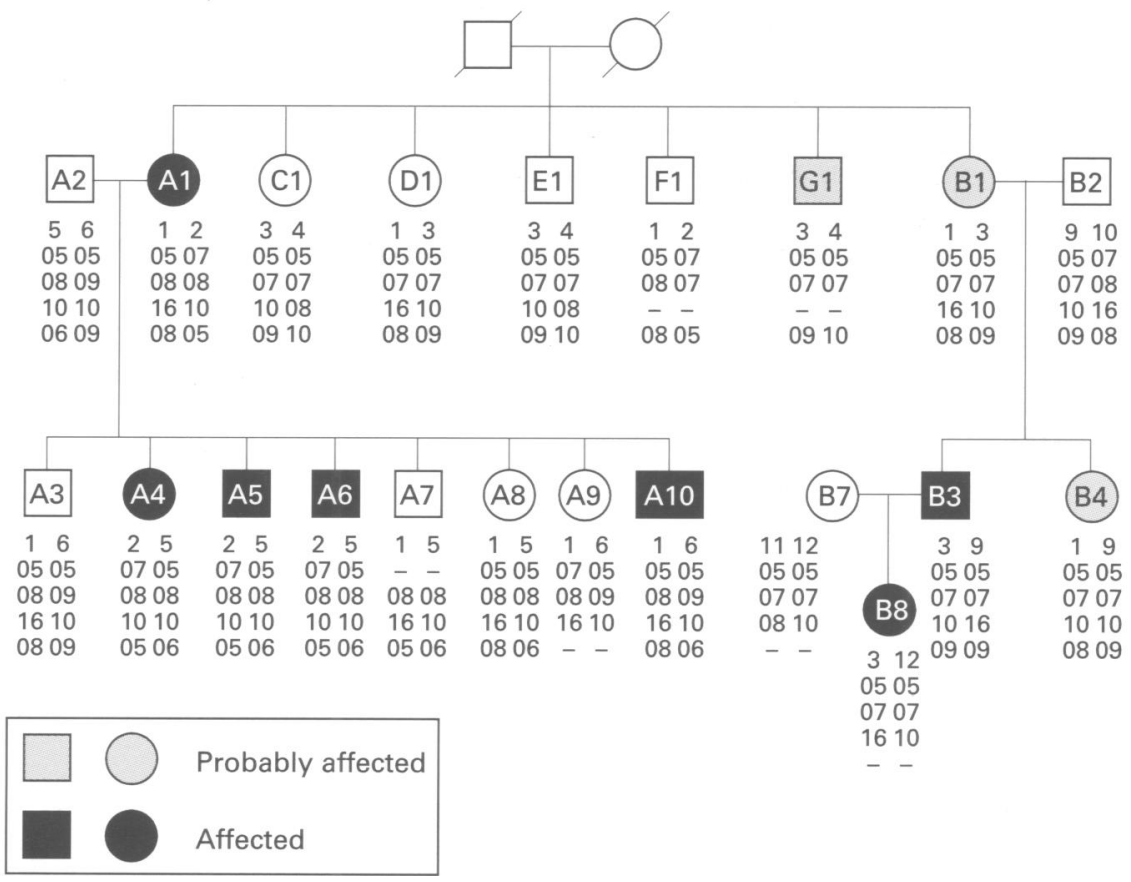

Figure 1 Genotypes for the four microsatellite markers arranged according to probable haplotypes in families $A$ and $B$. To facilitate pedigree drawing all family members have not been included. Top numbers indicate assigned haplotypes. No single haplotype is shared between affected members in either family.

The probability of a normal homozygote being diagnosed as affected was set at 0.001 for each age group, and the frequency of the abnormal allele was set to 0.00001 . For the multipoint analysis, the following map was used: D16S2830.04-D16S2617-0.08-D16S423. The genotypes obtained for the four markers in families $A$ and $B$ are shown in fig 1 , arranged according to probable haplotypes. Two point lod scores between the disease and markers, as shown in table 1 , are in general strongly negative in both these families and it is clear that no single haplotype is shared between affected subjects. Multipoint analysis results (fig 2) indicate that the exclusion region (lod less than -2) extends for over $30 \mathrm{cM}$ in family $A$ and about $24 \mathrm{cM}$ in family B, so MEFV has been excluded as a susceptibility locus for periodic fever(s) in these two families. There is insufficient power in family C for a definite result but the multipoint lod score at zero recombination is -1.03 . Localisation of the FHF gene(s) by genome screening with 


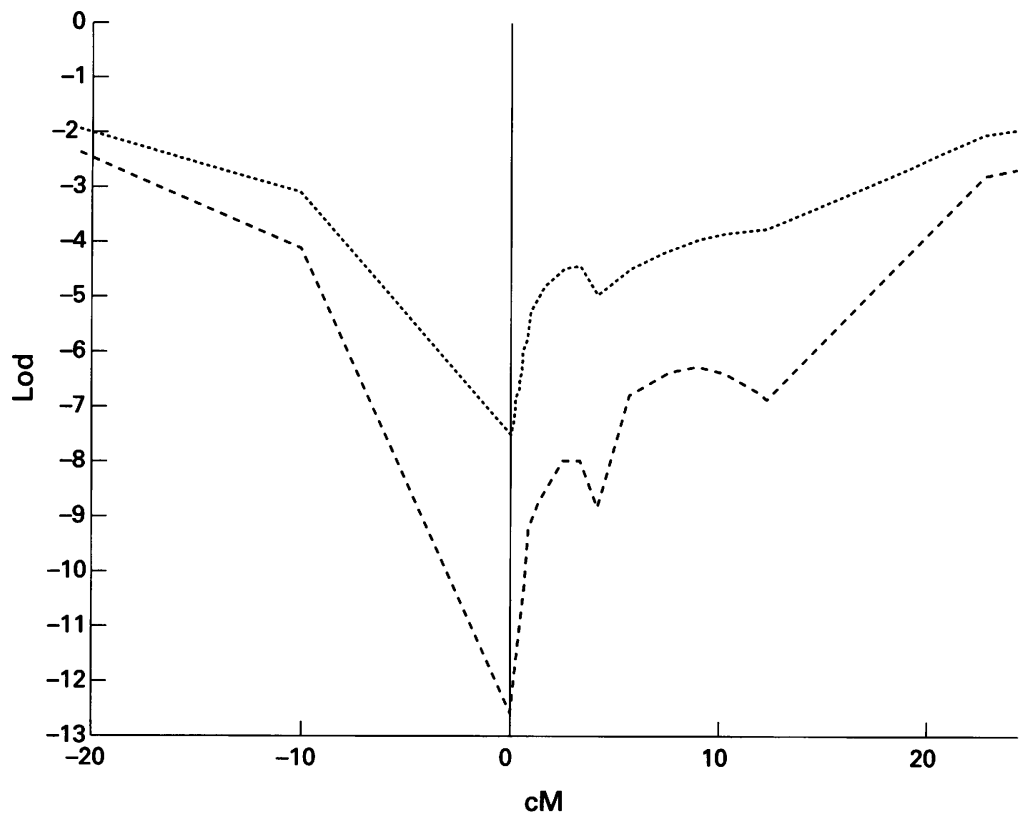

Figure 2 Multipoint lod scores in family $A$ (dashed line) and family $B$ (dotted line). The vertical axis indicates location of the first marker used to study these families (D16S283). The D16S2617 and D16S423 markers are placed respectively at 2-5 cM and 10-20 cM telomeric to D16S283. (D16S418 was not included in the multipoint analysis.)

subsequent identification of the genetic defect will indicate whether genetic heterogeneity of autosomal dominant periodic fever is present in these as well as other ethnically distinct families.

We are grateful to the families for agreeing to participate in the study. Dr Eithne Conway-McGee and Dr Phelim Donnelly (both from Galway) helped recruit the Irish based families. The work was supported by the Research Advisory Committee (RAC) of the Special Trustees, the Royal London Hospital NHS Trust. Dr E McDermott is supported by a Local Charitable Trust, Nottingham. F Waldron-Lynch is supported by a Health Research Board of Ireland (HRB) grant awarded to Professor F O'Gara (Department of Microbiology, National University of Ireland, Cork) and Dr M G Molloy.

1 Mache CJ, Goriup V, Fischel-Ghodsian N, Chen X, Schwingshandl J. Autosomal dominant familial Mediterranean fever-like syndrome. Eur $₹$ Pediatr 1996;155:787-90.
2 Zweers EJK, Erkelens DW. A Dutch family with familial Mediterranean fever. Ned Tijschr Geneeskd 1993;137:1570

3 Karenko L, Petterson T, Roberts P. Autosomal dominant "familial mediterranean fever" in a Finnish family. $\mathcal{f}$ In Med 1992;232:365-9.

4 Hawle H, Winckelmann G, St F Fortsik C. Familiares Mit telmeerfieber in einer deutschen Familie. Dtsch Med Wochenschr 1989;114:665-8.

5 McDermott EM, Smilie DM, Powell RJ. The clinical spectrum of familial Hibernian fever: a 14 year follow up study of the index and extended family. Mayo Clinic Proc 1997;72:806-17.

6 Quane KA, McDermott MF, McCarthy J, et al. Autosoma dominant periodic fever in two Irish pedigrees. $\mathrm{Br} ¥ \mathrm{Rheu}$ matol 1997:36(suppl 1):142.

7 Kastner DL. Intermittent and periodic arthritic syndromes. In: Koopmans W, ed. Arthritis and allied conditions: textbook of rheumatology. 13th ed. Baltimore: Williams and Wilkins, 1997:67, 1279-306.

8 Pras E, Aksentijevich I, Gruberg L, et al. Mapping of a gene causing familial Mediterranean fever to the short arm of chromosome 16. N Engl f Med 1992;326:1509-13.

9 The International FMF Consortium. Ancient missense mutations in a new member of the RoRet gene family are likely to cause familial Mediterranean fever. Cell 1997;90: 797-807.

10 The French FHF Consortium. A candidate gene for familial Mediterranean fever. Nat Genet 1997;17:25-31.

11 Akarsu AN, Saatci U, Ozen S, Bakkaloglu A, Besbas N, Sarfarazi $M$. Genetic linkage study of familial Mediterranean fever (FMF) to 16p13.3 and evidence for genetic heterogeneity in the Turkish population. $\mathcal{f}$ Med Genet 1997;34:573 8.

12 Yuval Y, Hemo-Zisser M, Zemer D, Sohar E, Pras M. Dominant inheritance in two families with familial Mediterranean fever (FMF). Am $\mathcal{F}$ Med Genet 1995;57: 455-7.

13 Drenth JP, Mariman EC, Van der Velde-Visser SD, Ropers HH, Van der Meer JW. International Hyper-IgD Study Group: location of the gene causing hyperimmunoglobulinemia $D$ and periodic fever syndrome differs from that for familial Mediterranean fever. Hum Genet 1994;94:616for fam
20.

14 Harris PC, Thomas S, Ratcliffe PJ, Breunig MH, Cotto E, Lopez-Larrea C. Rapid genetic analysis of families with polycystic disease 1 by means of a microsatellite marker. Lancet 1991;338:1484-7.

15 Gyapay G, Morissette J, Vignal A, et al. The 1993-1994 Genethon human genetic linkage map. Nat Genet 1994;7: 246-339.

16 Weissenbach J, Gyapay G, Dib C, et al. A second generation linkage map of the human genome. Nature 1992;359:794801.

17 Lathrop GM, Lalouel JM, Julier C, Ott J. Multilocus linkage analysis in humans: detection of linkage and estimation of recombination. Am $\mathcal{f}$ Hum Genet 1985;37:482-98. 